\title{
Evaluation of the genetic susceptibility to the metabolic syndrome by the CAPNIO SNPI 9 gene in the population of South Benin
}

\begin{abstract}
Metabolic syndrome is a multifactorial disorder whose etiology is resulting from the interaction between genetic and environmental factors. Calpain 10 (CAPN10) is the first gene associated with type 2 diabetes that has been identified by positional cloning with sequencing method. This gene codes for cysteine protease; ubiquitously expressed in all tissues, it is involved in the fundamental physiopathological aspects of insulin resistance and insulin secretion of type 2 diabetes. The goal of this study was to evaluate the genetic susceptibility to the metabolic syndrome by the CAPN10 gene in the population of southern Benin. This study involved apparently healthy individuals' aged 18 to 80 in four ethnic groups in southern Benin. It included 74 subjects with metabolic syndrome and 323 nonmetabolic syndrome patients who served as controls, with 222 women versus 175 men with an average age of $40.58 \pm 14.03$ years old. All subjects were genotyped for the SNP 19 polymorphism of the CAPN10 gene with the PCR method in order to find associations between this polymorphism and the metabolic syndrome. We found an association between this polymorphism and a risk of developing the metabolic syndrome only in the Tori and Nago ethnic groups. Genotype 1/1, a risk factor for the occurrence of the metabolic syndrome, is associated with environmental and nutritional factors in the four ethnic groups studied. The results of our study show that only the Goun and Nago ethnic groups have a genetic predisposition to the metabolic syndrome toward CAPN10 gene.
\end{abstract}

Keywords: metabolic syndrome, capn 10 gene, type 2 diabetes, ethnic groups, Southern

Benin
Volume 4 Issue 6 - 2019

\author{
Nicodème Worou Chabi, ${ }^{1,2}$ Basile G \\ Sognigbé,' Esther Duéguénon, ' Véronique BT \\ Tinéponanti,' Arnaud N Kohonou,' Victorien \\ T Dougnon, ${ }^{2}$ Lamine Baba Moussa' \\ 'Department of Biochemistry and Cell Biology, University of \\ Abomey-Calavi, Benin \\ ${ }^{2}$ Laboratory of Research in Applied Biology, Polytechnic School \\ of Abomey-Calavi, University of Abomey-Calavi, Benin
}

\begin{abstract}
Correspondence: Nicodème Worou Chabi, Laboratory of Biochemistry and Molecular Biology, Department of Biochemistry and Cell Biology, Faculty of Science and Technology, University of Abomey-Calavi, Benin, Tel +22997084906, Email nicodme.chabi@gmail.com
\end{abstract}

Received: November 19, 2019 | Published: December 09, 2019

\section{Introduction}

The metabolic syndrome is the coexistence of a set of metabolic aberrations, mainly, insulin resistance, obesity (general and abdominal), dysglycemia, dyslipidemia and high blood pressure. Its prevalence is $17.1 \%$ in southern Benin. Environmental factors such as ethnic group, age, sex, educational level, marital status, physical inactivity, overweight, non-regular consumption of fruits and vegetables and high cholesterol LDL are critical determinants of metabolic syndrome. ${ }^{2}$ In addition, genetic factors have contributed to individual susceptibility to metabolic syndrome. ${ }^{3,4}$

Many works have studied the associations between genetic polymorphisms and the various components of the metabolic syndrome. Very few, on the other hand, have explored this association with the metabolic syndrome as an entity, that is, according to the criteria of the International Diabetes Federation. ${ }^{5}$ These studies have shown that variations in the calpain 10 gene (CAPN10) are significantly associated with the metabolic syndrome. ${ }^{6}$ The Calpain 10 is the first gene with 2-of-the-Genome-Human-Key-to-Buy with Positional Cloning and Sequencing. Located on the short arm of chromosome 2 (2p.37.3), this gene codes for one over the protein of proteases $;^{7}$ ubiquitously expressed in all tissues, in the fundamental pathophysiological aspects of insulin resistance and insulin secretion of type 2 diabetes. ${ }^{8}$ In addition, the CAPN10 gene is associated with cholesterol levels and blood pressure. ${ }^{6}$

A recent study has shown an association between the SNP19 polymorphism of the calpain 10 gene with type 2 diabetes in an ethnic group in the Tunisian populations. Allele 2 has been reported to provide protection against the onset of type 2 diabetes, but Allele 1 is a risk factor and should be considered in the assessment of a predisposition to such conditions. as diabetes, obesity, metabolic syndrome diseases, high blood pressure and cardiovascular diseases. The objective of this work was to evaluate the genetic susceptibility to the metabolic syndrome by the CAPN10 gene in the population of southern Benin.

\section{Material and methods}

\section{Topics analyzed}

The participants were recruited as part of the study on the metabolic syndrome in the three communes of southern Benin in 2018: the commune of Avrankou in the department of Ouémé; the communes of Ifangni and Sakété in the plateau department. The sample includes individuals aged 18 to 80 randomly selected from four ethnic groups. The first condition for inclusion in this study is to be an adult and to have participated in the two previous studies. ${ }^{2}$ The second is to belong to one of the Goun, Tori, Nago and Yoruba ethnic groups. The third condition is to have accepted to participate in the study and to have given written consent. The subjects are distributed as follows: 74 with the metabolic syndrome and 360 healthy subjects. Subjects with the metabolic syndrome were detected based on criteria from the International Diabetes Federation. The characteristics of the study population are summarized in Tables $1 \& 2$. 
Table I Distribution of metabolic syndrome according to IDF criteria ${ }^{2}$

\begin{tabular}{|c|c|c|c|}
\hline \multirow[b]{2}{*}{ Parameters } & \multicolumn{2}{|c|}{ Metabolic syndrome } & \multirow[b]{2}{*}{ p-value } \\
\hline & Presence (n/\%) & $\begin{array}{l}\text { Absence } \\
(n / \%)\end{array}$ & \\
\hline Age $<40$ & $18(7.8)$ & $212(92.2)$ & 0 \\
\hline Age $\geq 40$ & $56(27.5)$ & I 48 (72.5) & \\
\hline Female & $61(25.7)$ & $176(74.3)$ & 0 \\
\hline Male & $13(6.6)$ & $184(93.4)$ & \\
\hline Educated & $23(10.5)$ & $196(89.5)$ & 0 \\
\hline Not educated & $5 \mathrm{I}(23.7)$ & $164(76.3)$ & \\
\hline Married & $67(19.1)$ & $284(80.9)$ & 0.02 \\
\hline Not married & $7(8.4)$ & $76(91.6)$ & \\
\hline History of HTA & $10(14.5)$ & $59(85.5)$ & 0.537 \\
\hline $\begin{array}{l}\text { No history of } \\
\text { hypertension }\end{array}$ & $64(17.5)$ & $301(82.5)$ & \\
\hline History of diabetes & I (7.7) & $12(92.3)$ & 0.362 \\
\hline No history of diabetes & $73(17.3)$ & $348(82.7)$ & \\
\hline Regular physical activity & I (2.3) & $42(97.7)$ & 0.006 \\
\hline $\begin{array}{l}\text { No regular physical } \\
\text { activity }\end{array}$ & $73(18.7)$ & $31(81.3)$ & \\
\hline $\mathrm{IMC}<25 \mathrm{~kg} / \mathrm{m}^{2}$ & $20(6.9)$ & $268(93.1)$ & 0 \\
\hline $\mathrm{IMC} \geq 25 \mathrm{~kg} / \mathrm{m}^{2}$ & $54(37.0)$ & $92(63.0)$ & \\
\hline
\end{tabular}

The data is expressed in n (\%); HTA = Hypertension; BMI = Body Mass Index

Table 2 Nutritional factors associated with metabolic syndrome ${ }^{2}$

\begin{tabular}{|c|c|c|c|}
\hline \multirow[b]{2}{*}{ Parameters } & \multicolumn{3}{|c|}{ Metabolic syndrome } \\
\hline & $\begin{array}{l}\text { Presence } \\
(\mathrm{n} / \%)\end{array}$ & $\begin{array}{l}\text { Absence } \\
(\mathrm{n} / \%)\end{array}$ & P-value \\
\hline Alcohol consumption & $37(19.8)$ & $150(80.2)$ & 0.187 \\
\hline No alcohol consumption & $37(15.0)$ & $210(85.0)$ & \\
\hline Tobacco consumption & $5(19.2)$ & $21(80.8)$ & 0.76 \\
\hline No smoking & $69(16.9)$ & $33(83.1)$ & \\
\hline $\begin{array}{l}\text { Regular consumption of fruits } \\
\text { and vegetables }\end{array}$ & $2(4.6)$ & $4 \mathrm{I}(95.4)$ & 0.022 \\
\hline $\begin{array}{l}\text { No regular consumption of } \\
\text { fruits and vegetables }\end{array}$ & $72(18.4)$ & $319(81.6)$ & \\
\hline Total hypercholesterolemia & $15(24.2)$ & $47(75.8)$ & 0.106 \\
\hline $\begin{array}{l}\text { No total } \\
\text { hypercholesterolemia }\end{array}$ & $59(15.9)$ & $313(84.1)$ & \\
\hline LDL hypercholesterolemia & $4 \mid(27.5)$ & $108(72.5)$ & 0 \\
\hline $\begin{array}{l}\text { No LDL } \\
\text { hypercholesterolemia }\end{array}$ & $33(11.6)$ & $252(88.4)$ & \\
\hline
\end{tabular}

Data are expressed in $n(\%)$

\section{Data gathering}

This study uses data from previous studies, including data on age, weight, height, sex, regular consumption of fruits and vegetables, lifestyle, level of education, diet, socio-economic conditions, physical activity and biochemical parameters. ${ }^{2}$

\section{Methods}

DNA extraction: The genomic DNA of participants with or without metabolic syndrome of the four ethnic groups was extracted from leukocytes from $10 \mathrm{ml}$ of EDTA whole blood, using a DNA isolation kit (Kit Nucleon Bac Pharmacia-Biotch from Amersham Company) in the Laboratory of Biochemistry and Molecular Biology located at the Institute of Applied Biomedical Sciences (ISBA) in Cotonou, Benin. The optical density was taken using a Nanodrop Lite 8000 spectrophotometer from Thermo Scientific.

Genotyping: Genotyping of the UCSNP19 polymorphism of the calpain gene consists of an insertion/deletion characterized by a two or three-fold repetition of a $32 \mathrm{bp}$ sequence. ${ }^{7}$ The detection of the UCSNP19 mutation of the calpain 10 gene was carried out by PCR amplification according to the protocol described by Baroudi using the following primers: F: 5'-GTT TGG TTC TCT TCA GCG TGG AG - 3'and R: 5'-CAT GAA CCC TGG CAG GGT CTA AG3. The genomic DNA (50 ng) was amplified in a final volume of 25 .mu.1, containing $1 \mu \mathrm{mol} / \mathrm{L}$ of each primer, $1 \mathrm{mM}$ of dNTP, $1.5 \mathrm{~mol} / \mathrm{L}$ of $\mathrm{MgCl}_{2}, 5 \mu \mathrm{L}$ of the $5 \mathrm{X}$ PCR buffer and $0.25 \mathrm{U}$ of the GoTaq DNA polymerase (Promega). The amplification conditions were as follows: an initial denaturation at $95^{\circ} \mathrm{C}$ for 5 minutes, 30 PCR cycles each comprising denaturation at $94^{\circ} \mathrm{C}$ for $60 \mathrm{sec}$, hybridization at $55^{\circ} \mathrm{C}$ for $60 \mathrm{sec}$, extension at $72^{\circ} \mathrm{C}$ for $60 \mathrm{sec}$ and finally a final elongation at $72^{\circ} \mathrm{C}$ for 10 minutes.

The PCR products were separated by agarose gel electrophoresis at $2 \%$ gel stained with $5 \mu \mathrm{g} / \mathrm{ml}$ red gel. A $100 \mathrm{bp}$ DNA molecular weight marker (ladder) was used to compare the size of amplification fragments. The migration was performed at a scale of $80 \mathrm{~V} / \mathrm{cm}$ for $30 \mathrm{~min}$. The revelation was made by ultraviolet light. The presence of the wild-type allele 1 results in the visualization of a 155 bp band (deletion of the $32 \mathrm{bp}$ repeat) and that of the allele 2 by that of a 187 bp band (insertion of the repetition $32 \mathrm{bp}$ ).

\section{Statistical analysis}

The information collected was analyzed using Excel and $\mathrm{R}$ version 3.2.2 with the FactoMineR package. Quantitative data were presented by averages and standard deviation (SD) and qualitative data by their size (n) and proportion (\%). The deviation of the Hardy-Weinberg equilibrium was tested using the $\chi^{2}(1 \mathrm{df})$ test. The statistical calculation is based on the use of Student's t-test. Allelic and genotypic frequencies were compared by a $\chi 2$ test. The relative risk associated with the genotype was estimated by calculating the odds ratio $(\mathrm{OR})$ at $95 \%[\mathrm{CI}]$. We assessed the association between CAPN10 genotypes and risk factors associated with metabolic syndrome using logistic regression (OR and 95\% [CI]). The 0.05 threshold was used for statistical significance.

\section{Results}

\section{Sociodemographic characteristics of the study population}

A total of 397 subjects were included in this study in both departments. Among them 175 (44.08\%) were male and 222 (55.92\%) female with a sex ratio of 0.79 .

The mean age of men was $38.89 \pm 12.78$ compared to $41.90 \pm 14.83$ for women. The average age of the participants was $40.58 \pm 14.03$ with extremes of 18 to 80 years (Table 3). 
Table 3 Sociodemographic characteristics of the study population

\begin{tabular}{|c|c|c|c|}
\hline \multirow{2}{*}{ Parameters } & Male & Female & Total \\
\hline & $n=175$ & $n=222$ & $n=397$ \\
\hline Average age (years) & $38,89 \pm 12,78$ & $41.90 \pm 14,83$ & $40,58 \pm 14,03$ \\
\hline \multicolumn{4}{|l|}{ level of education } \\
\hline No & $53(25.98)$ & I5I (74.02) & 204 (5I.39) \\
\hline Primary & 46 (59.74) & $31(40.26)$ & 77 (19.40) \\
\hline Secondary & $54(58.70)$ & $38(4 I .30)$ & $92(23.17)$ \\
\hline Superior & 22 (91.67) & $2(8.33)$ & $24(6.05)$ \\
\hline \multicolumn{4}{|l|}{ Marital status } \\
\hline Single & 31 (67.39) & I5 (32.6I) & 46 (II.59) \\
\hline Married & I 42 (44.24) & 179 (55.76) & 321 (80.86) \\
\hline $\begin{array}{l}\text { Divorced or } \\
\text { widowed }\end{array}$ & $2(6.67)$ & $28(93.33)$ & $30(7.56)$ \\
\hline \multicolumn{4}{|l|}{ Ethnic group } \\
\hline Goun & $56(45.16)$ & $68(54.84)$ & $124(31.23)$ \\
\hline Tori & $60(46.88)$ & $68(53.13)$ & $130(32.75)$ \\
\hline Nago & $44(41.90)$ & $61(58.10)$ & $103(25.94)$ \\
\hline Yoruba & I5 (37.50) & $25(62.50)$ & $40(10.08)$ \\
\hline
\end{tabular}

Data expressed as mean \pm SD or frequency $(\%)$

\section{Clinical characteristics of the study population}

Table 4 presents the clinical characteristics of subjects with metabolic syndrome as well as apparently healthy subjects. From the analysis of the table, it appears that from clinical parameters, there is a statistically significant difference between the two groups of subjects.

Table 4 Clinical characteristics of subjects with metabolic syndrome and healthy subjects

\begin{tabular}{|c|c|c|c|}
\hline \multicolumn{4}{|l|}{ Metabolic syndrome } \\
\hline & Presence & Absence & p-value \\
\hline \multicolumn{4}{|l|}{ Parameters } \\
\hline Total number (F / M) & $74(6 / / / 3)$ & $323(161 / 162)$ & $3.526 \mathrm{E}-07^{*}$ \\
\hline Average age (years) & $48,31 \pm 12,89$ & $38,80 \pm 13,69$ & I.I8E-07* \\
\hline Weight in kg & $74,00 \pm 15,27$ & $62,48 \pm 12,19$ & $2.66 \mathrm{E}-08^{*}$ \\
\hline BMI (kg / m2) & $28,2 I \pm 5,4 I$ & $22,97 \pm 4,0$ I & $6.66 \mathrm{E}-12^{*}$ \\
\hline $\mathrm{TT}$ in $\mathrm{cm}$ & $93,88 \pm 10,89$ & $80,98 \pm 10,07$ & $2.39 \mathrm{E}-15^{*}$ \\
\hline NOT in $\mathrm{mmHg}$ & $147,23 \pm 22,20$ & $123,66 \pm 19,67$ & $2.86 \mathrm{E}-13^{*}$ \\
\hline PAD in $\mathrm{mmHg}$ & $91,85 \pm 12,37$ & $78,15 \pm 12,94$ & $8.08 \mathrm{E}-14^{*}$ \\
\hline Glycemia in $\mathrm{g} / \mathrm{I}$ & $\mathrm{I}, 00 \pm 0,27$ & $0,8 I \pm 0,16$ & I.06E-08* \\
\hline Triglycerides in g / I & $\mathrm{I}, \mid 4 \pm 0,5 \mathrm{I}$ & $0,85 \pm 0,31$ & I. $10 \mathrm{E}-05^{*}$ \\
\hline HDL-cholesterol in $\mathrm{g} / \mathrm{I}$ & $0,43 \pm 0,11$ & $0,55 \pm 0,17$ & $5.2 \mathrm{IE}-13^{*}$ \\
\hline
\end{tabular}

Data expressed as mean \pm SD or frequency $(\%) ; *$ statistically significant

\section{The different fragments observed with the UV lamp}

The gel photograph identified the different genotypes in the study population (Figure 1).

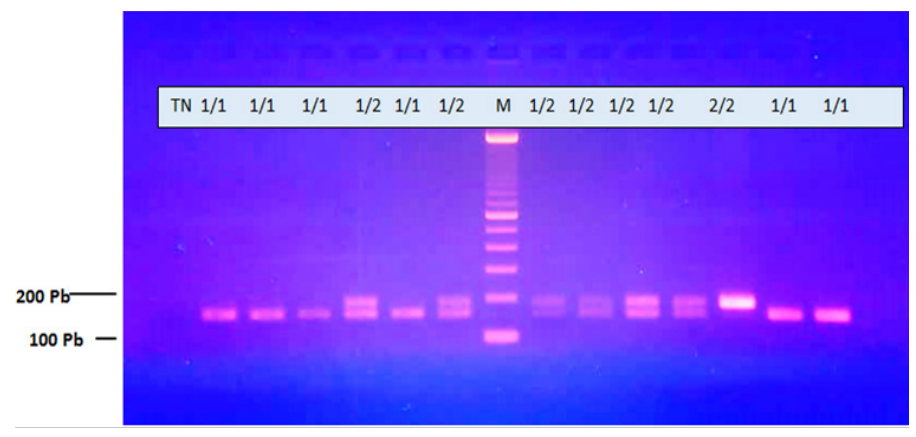

Figure I Migration photo of fragments CAPNIO gene amplification.

M: molecular weight marker, TN: negative control, I/I: I55 bp, I/2: I55 and 187, 2/2: 187bp.

Genotypic and allelic distribution of the SNP 19 mutation of the CAPN 10 gene in the study population

The analysis of the UCSNP19 polymorphism of the CAPN 10 gene allowed us to estimate the frequency of the allele 2 in the population with the metabolic syndrome where it was equal to $16.7 \%, 34.2 \%$, $23.8 \%$ and $46.2 \%$ respectively in the Goun, Tori, Nago and Yoruba. In the apparently healthy individuals of the Goun, Tori, Nago and Yoruba ethnic groups, this frequency is respectively $40.3 \%$, 38.3\%, $59.9 \%$ and $40.7 \%$. In the Tori and Yoruba ethnic groups, the genotypic distribution is consistent with Hardy Weinberg's equilibrium. On the other hand, at Goun and Nago we notice a deviation of Hardy Weinberg's equilibrium (Table 5).

The same table shows that in Goun metabolic syndrome carriers, 16 (76.2\%) were homozygous $1 / 1,3(14.3 \%)$ were heterozygous $1 / 2$ and $2(9.5 \%)$ were homozygous $2 / 2$. In Tori metabolic syndrome carriers, $9(47.4 \%)$ were homozygous $1 / 1,7$ (36.8\%) were heterozygous $1 / 2$ and 3 subjects $(15.8 \%)$ were homozygous $2 / 2$. In Nago metabolic syndrome carriers, 14 (66.7\%) were homozygous 1/1, 4 (19.0\%) were heterozygous $1 / 2$ and $3(14.3 \%$ ) were homozygous $2 / 2$. In Yoruba metabolic syndrome carriers, 4 (30.8\%) were homozygous $1 / 1,6$ $(46.2 \%)$ were heterozygous $1 / 2$ and $3(23.1 \%)$ were homozygous $2 / 2$. The table does not show a statistically significant difference in the genotypic distribution between the Tori and Yoruba ethnic groups ( $\mathrm{p}=0.883$ and $\mathrm{p}=0.57$ respectively). On the other hand, there is a statistically significant difference in the genotypic distribution between the Goun and Nago ethnic groups $(\mathrm{p}=0.009$ and $\mathrm{p}=0.006$ respectively). The statistical analysis performed in the four ethnic groups showed a different association between the studied marker and the susceptibility to the metabolic syndrome. Indeed, the study of the allelic and genotypic distribution shows only in Goun and Nago that the allele 2 is a protective factor; on the other hand, the allele 1 seems to be a risk factor for the metabolic syndrome, $[\mathrm{p}=0.004 ; \mathrm{OR}=3.36(1.38$ 9.40) and $\mathrm{p}=0.000 ; \mathrm{OR}=4.37$ (1.94-10.36) respectively]. Moreover, in Tori and Yoruba, no significant association was observed between the carriers of metabolic syndrome and the apparently healthy individuals allowed to define the polymorphism of CAPN 10 as a neutral marker with metabolic syndrome (Table 5).

Multivariate logistic regression analysis did not show a difference in genotype distribution $1 / 1$ by age, educational level, marital status and regular consumption of fruits and vegetables $(\mathrm{p}>0.05)$. In contrast, a statistically significant difference was found by sex, physical activity, BMI, blood glucose, HDL cholesterol and triglyceride levels $(\mathrm{p}<0.05)$ (Table 6). 
Table 5 Genotypic and allelic frequencies of the SNP 19 mutation of the CAPNI0 gene in the population of southern Benin

\begin{tabular}{|c|c|c|c|c|c|c|c|c|}
\hline & \multicolumn{4}{|c|}{ Genotype (\%) } & \multicolumn{4}{|l|}{ Allèle (\%) } \\
\hline & $\mathbf{I} / / \mathbf{I}$ & $\mathrm{I} / / 2$ & $2 / / 2$ & $\mathbf{P}$ & I* & 2 & OR $(95 \% \mathrm{CI})$ & $\mathbf{P}$ \\
\hline \multicolumn{9}{|l|}{ Study population } \\
\hline SMet presence $(n=74)$ & $43(58.1)$ & $20(27.0)$ & II(I4.9) & $0.008^{*}$ & $106(71.6)$ & $42(28.4)$ & $1.96(1.31-2.97)$ & $0.00 I^{*}$ \\
\hline Absence SMet $(n=323)$ & $127(39.3)$ & $107(33.1)$ & $89(27.6)$ & & $360(56.2)$ & $280(43.8)$ & & \\
\hline \multicolumn{9}{|l|}{ GOUN } \\
\hline SMet presence $(n=2 I)$ & $16(76.2)$ & $3(14.3)$ & $2(9.5)$ & $0.009 *$ & $35(83.3)$ & $7(16.7)$ & $3.36(1.38-9.40)$ & $0.004^{*}$ \\
\hline Absence SMet $(n=103)$ & $4 I(39.8)$ & $4 I(39.8)$ & $21(20.4)$ & & $123(59.7)$ & $83(40.3)$ & & \\
\hline \multicolumn{9}{|l|}{ TORI } \\
\hline SMet presence $(n=19)$ & $9(47.4)$ & $7(36.8)$ & $3(15.8)$ & 0.883 & $25(65.8)$ & $13(34.2)$ & I. I $9(0.55-2.68)$ & 0.718 \\
\hline Absence SMet $(\mathrm{n}=\mathrm{III})$ & $49(44.1)$ & $39(35.1)$ & $23(20.7)$ & & $137(61.7)$ & $85(38.3)$ & & \\
\hline \multicolumn{9}{|l|}{ NAGO } \\
\hline SMet presence $(n=2 I)$ & $14(66.7)$ & $4(19.0)$ & $3(14.3)$ & $0.006 *$ & $32(76.2)$ & $10(23.8)$ & $4.37(1.94-10.66)$ & $0.000 *$ \\
\hline Absence SMet $(\mathrm{n}=82)$ & $25(30.5)$ & $19(23.2)$ & $38(46.3)$ & & $69(42.1)$ & $95(57.9)$ & & \\
\hline \multicolumn{9}{|l|}{ YORUBA } \\
\hline SMet presence $(n=13)$ & $4(30.8)$ & $6(46.2)$ & $3(23.1)$ & 0.57 & I4(53.8) & $12(46.2)$ & & \\
\hline Absence SMet $(\mathrm{n}=27)$ & $12(44.4)$ & $8(29.6)$ & $7(25.9)$ & & $32(59.3)$ & $22(40.7)$ & $0.80(0.28-2.30)$ & 0.809 \\
\hline
\end{tabular}

* Statistiquement significant

Table 6 Logistic regression by metabolic syndrome as dependent variable

\begin{tabular}{llll}
\hline & B & SE & P \\
\hline SMet versus healthy & & & \\
Age & -0.011 & 0.019 & 0.567 \\
Sex & -4.084 & 0.85 & $1.55 \mathrm{e}-06 *$ \\
Level of education & -0.828 & 0.622 & 0.183 \\
Marital status & 0.008 & 0.035 & 0.8 \\
Physical activity & 0.327 & 1.487 & $0.002396 *$ \\
Cons fruit & 0.468 & 0.698 & 0.502 \\
BMI & -0.057 & 0.098 & $0.000279 *$ \\
Blood Sugar & -0.057 & 0.018 & $0.002396 *$ \\
Chol HDL & 14.154 & 2.431 & $5.87 \mathrm{e}-09 *$ \\
Triglycerides & -3.194 & 0.715 & $8.09 \mathrm{e}-06 *$ \\
\hline
\end{tabular}

* Statistically significant

\section{Discussion}

The present study is, to our knowledge, the first study carried out in Benin in the exploration of the genetic susceptibility to the metabolic syndrome in a population in apparent health. It allowed to study the UCSNP19 polymorphism of the CAPN10 gene in relation to environmental and nutritional factors in a population of 397 subjects with or without metabolic syndrome. To achieve this, we used a candidate gene approach and conducted an association study between the UCSNP19 polymorphism and the risk of metabolic syndrome ${ }^{3,9}$ in four (4) ethnic groups in southern Benin. We looked at the CAPN10 gene encoding cysteine protease because, based on literature data, it is involved in the basic physiopathological aspects of insulin resistance and insulin secretion of type 2 diabetes. ${ }^{8}$ It is therefore a good gene 
candidate relevant for the evaluation of a genetic predisposition to the occurrence of the metabolic syndrome. The study population was young, consisting of 397 individuals with an average age of 40.58 \pm 14.03 . This sample size is fairly representative of the southern Benin population for evaluating allelic and genotypic frequencies. Our sample is similar in size to that of a study in Polish European populations, ${ }^{10}$ but it is higher than that of Baroudi.

The statistical analyzes performed in the four ethnic groups show different associations between the studied marker and the genetic susceptibility to the metabolic syndrome. In fact, allelic and genotypic distributions allowed to define the risk factors only in Goun and Nago, in which allele 1 constitutes a risk factor $[\mathrm{p}=0.004$; $\mathrm{OR}=3.36$ (1.38-9.40) and $\mathrm{p}=0.000 ; \mathrm{OR}=4.37$ (1.94-10.36)]; however, the allele 2 seems to be protective against the metabolic syndrome. In the Tori and Yoruba ethnic groups, there is not a significant difference between metabolic syndrome carriers and apparently healthy subjects for defining SNP19 polymorphism as a neutral marker for metabolic syndrome. This study confirms the difference between ethnic groups in the genetic predisposition to metabolic syndrome as reported in the literature. ${ }^{11}$

One of the explanatory factors for this difference is the environment. Indeed, in these four ethnic groups of the population of southern Benin, there is a disparity $(\mathrm{p}=0.009)$ in the distribution of BMI to obesity (BMI $\left.\geq 30 \mathrm{Kg} / \mathrm{m}^{2}\right){ }^{2}$ The heterogeneity of the distribution of the SNP19 polymorphism of the CAPN 10 gene is multifactorial and illustrates well the gene-environment interactions. Indeed, we also analyzed the interaction of environmental parameters (physical activity, educational level, marital status, and BMI) and nutritional (regular consumption of fruits and vegetables, blood glucose, HDL cholesterol and triglycerides) with genotype 1/1 (Table 6). In our study population, we found an association between genotype 1/1 and sex, physical activity, BMI, blood glucose, HDL cholesterol and triglyceride. The results of this study suggest that environmental and nutritional factors greatly affect population health. Indeed, the four ethnic groups have almost the same eating habits composed largely of oil and starchy foods. ${ }^{2}$ This type of diet favors the metabolic syndrome. ${ }^{12-14}$

\section{Conclusion}

The results of our study show that only the Goun and Nago ethnic groups have a genetic predisposition to metabolic syndrome with SNP19 of CAPN10 gene. Genotype 1/1, a risk factor for the occurrence of metabolic syndrome, is associated with environmental and nutritional factors in the four ethnic groups studied.

\section{Acknowledgments}

None.

\section{Conflicts of interest}

The author declares there are no conflicts of interest.

\section{References}

1. Capeau, Jacqueline, Jean Philippe Bastard, et al. Metabolic syndrome and insulin resistance: Pathophysiology. Medecine Therapeutique Cardio. 2006;2(2):155-164.

2. Basile G Sognigbé, Nicodème Worou Chabi, Victorien T Dougnon, et al. Prevalence of metabolic syndrome and associated risk factors in the population of southern Benin. Int J Biosci. 2019;15(5):205-217.

3. Teran Garcia M, Bouchard C. Genetics of the metabolic syndrome. Appl Physiol Nutr Metab. 2007;32(1):89-114.

4. Liese AD, Mayer Davis EJ, Tyroler HA, et al. Familial component of the multiple metabolic syndrome: The ARIC study. Diabetologia. 1997;40(8):963-970.

5. Procopiou Michel, Jacques Philippe. The metabolic syndrome and type 2 diabetes: Epidemiological figures and country specificities. Cerebrovasc Dis. 2005;20(Supply 1):2-8.

6. Saez ME, Gonzalez Sanchez JL, Ramirez Lorca R, et al. The CAPN10 gene is associated with insulin resistance phenotypes in the Spanish population . PLOS ONE. 2008;3:2953.

7. Hanis CL, E Boerwinkle, Chakraborty R, et al. A genome-wide search for human non-insulin-dependent (type 2) diabetes genes reveals a major susceptibility locus on chromosome 2. Nat Genet. 1996;13(2):161-166.

8. Horikawa Y, N Oda, Cox NJ, et al. Genetic variation in the gene encoding calpain-10 is associated with type 2 diabetes mellitus. Nat Genet. 2000;26(2):163-175.

9. Legry V, L Goumidi, M Huyvaert, et al. Association between angiopoietin-like 6 (ANGPTL6) gene polymorphisms and metabolic syndrome-related phenotypes in the French MONICA Study. Diabetes Metab. 2009;35(4):287-292.

10. Malecki MT, Moczulski DK, Klupa T, et al. Homozygous combination of calpain 10 gene haplotypes is associated with type 2 diabetes mellitus in a Polish population. Eur J Endocrinol. 2002;146(5):695-699.

11. Ford Earl S, Wayne H Giles, William H Dietz. Prevalence of the Metabolic Syndrome Among US Adults. JAMA. 2002;287(3):356-359.

12. Park YW, Zhu S, Palaniappan L, et al. The metabolic syndrome: prevalence and associated risk factors findings in the US population from the Third National Health and Nutrition Examination Survey, 1988-1994. Arch Intern Med. 2003;163(4):427-436.

13. Chen Wei, Sathanur R Srinivasan, Abdalla Elkasabany, et al. The association of cardiovascular risk factor clustering related to insulin resistance syndrome (Syndrome $\mathrm{X}$ ) between young parents and their offspring: The Bogalusa Heart Study. Atherosclerosis. 1999;145(1):197_ 205.

14. Ouederni TB, Sanchez Corona J, Skhiri HA, et al. Study of association of the SNP19 polymorphism of calpain 10 gene with type 2 diabetes in ethnic sub-groups of the Tunisian population: gene-environment interaction. Ann Biol Clin (Paris). 2009;67(2):171-176. 